\title{
Molybdenum supply and biological fixation of nitrogen by two Brazilian common bean cultivars
}

\author{
Alinne da Silva ${ }^{1}$, Vinícius I. Franzini ${ }^{2}$, Cristiano D. Piccolla ${ }^{3} \&$ Takashi Muraoka ${ }^{4}$ \\ ${ }^{1}$ Universidade Estadual da Região Tocantinal/Centro de Ciências Agrárias. Imperatriz, MA. E-mail: alinneagro@hotmail.com (Corresponding author) \\ ${ }^{2}$ Empresa Brasileira de Pesquisa Agropecuária/Embrapa Amazônia Oriental. Belém, PR. E-mail: vinícius.franzini@embrapa.com \\ ${ }^{3}$ Universidade de São Paulo/Escola Superior de Agricultura "Luiz de Queiroz". Piracicaba, SP. E-mail: cristianop@usp.br \\ ${ }^{4}$ Universidade de São Paulo/Centro de Energia Nuclear na Agricultura. Piracicaba, SP. E-mail: muraoka@cena.usp.br
}

\section{Key words:}

isotope dilution

labeled fertilizer

rhizobia

\begin{abstract}
A B S T R A C T
The common bean has been considered to have low biological nitrogen fixation capacity; however, this process can be made more effective with molybdenum (Mo) supplementation. The objective of this study was to evaluate the influence of Mo rates on the growth and biological nitrogen fixation by two Brazilian common bean cultivars using the ${ }^{15} \mathrm{~N}$ isotope dilution technique. The experiment was performed in 2014 in a completely randomized design arranged in a $5 \times 3$ factorial scheme, corresponding to 5 rates of Mo (control, 40, 80, 120 and $240 \mathrm{~g} \mathrm{ha}^{-1}$ ), the common bean cultivars Aporé, Ouro Negro and NORH-54 (a non-nodulating common bean cultivar), and three replicates. The application of Mo and the inoculation with rhizobia strains contributed to improving nitrogen fixation and grain weight. The cultivar Ouro Negro showed a higher number and weight of nodules and a higher amount of nitrogen derived from the atmosphere than the cultivar Aporé. The biological nitrogen fixation of Aporé was more dependent on the application of Mo. These results indicated that inoculation with Rhizobium strains and Mo supply effectively contributed to biological nitrogen fixation and improving grain production.
\end{abstract}

Palavras-chave:

diluição isotópica fertilizante marcado rizóbio

\section{Fornecimento de molibdênio e fixação biológica de nitrogênio em duas cultivares brasileiras de feijão comum}

\begin{abstract}
R E S U M O
O feijão apresenta baixa capacidade de fixação biológica de nitrogênio, o qual pode ser mais eficiente com o fornecimento de molibdênio (Mo). O objetivo deste estudo foi avaliar doses de Mo no crescimento e na fixação biológica de nitrogênio em duas cultivares de feijoeiro usando a técnica de diluição isotópica. O experimento foi realizado em 2014 em delineamento inteiramente casualizado e em esquema fatorial 5 × 3, correspondendo a cinco doses de Mo (controle, 40, 80, 120 e $240 \mathrm{~g} \mathrm{ha}^{-1}$ ), cultivares de feijoeiro Aporé, Ouro Negro e NORH-54, cultivar de feijão não nodulante e três repetições. A aplicação de Mo e a inoculação das sementes com uma estirpe de rizóbio contribuíram para melhorar a fixação de nitrogênio e o peso de grãos. A cultivar Ouro Negro apresentou maior número e peso de nódulos do que a cultivar Aporé e maiores valores de nitrogênio proveniente da atmosfera. A fixação biológica do nitrogênio foi mais dependente da aplicação de Mo na cultivar Aporé. Esses resultados indicaram que a inoculação com rizóbio e o fornecimento de Mo contribuíram com a fixação biológica de nitrogênio e produção de grãos.
\end{abstract}




\section{INTRODUCTION}

The common bean (Phaseolus vulgaris L.) is a staple food in many Latin American and African countries, regarded as a primary source of daily proteins and minerals. The carioca and black common bean group are the two most consumed types in Brazil (Vogt et al., 2013), cultivated mainly by small holder farmers.

It is well established that leguminous plants in association with Rhizobium sp. can use atmospheric $\mathrm{N}_{2}$ (Marschner, 2012; Boyd \& Peters, 2013). However, the common bean has been considered to have low biological $\mathrm{N}_{2}$ fixation (BNF) capacity compared to other legumes, such as soybean (Piha \& Munns, 1987).

Although the common bean can form symbiosis with a wide range of indigenous rhizobia, these rhizobia have been considered low efficiency for BNF, in addition to having a short vegetative fixation period (Piha \& Munns, 1987). However, inoculating the common bean with selected rhizobia strains could increase the $\mathrm{N}_{2}$ fixation, as expressed by higher $\mathrm{N}$ content in plant tissues, demonstrated by Hungria et al. (2003) and Kimura et al. (2004).

In addition to inoculation with selected strains, the BNF in the common bean can be made more effective by molybdenum (Mo) supplementation. Mo plays an essential role in many biochemical processes in plants and is a constituent of nitrogenase (Fageria et al., 2011; Marschner, 2012), the enzyme that catalyzes the reduction of atmospheric nitrogen into ammonia, and a cofactor in nitrate reductase.

Due to the role of Mo in the mechanisms associated with the regulation of $\mathrm{N}_{2}$ fixation in legumes, Mo supplementation has increased $\mathrm{N}$ accumulation and grain yield in common beans, as reported by several authors (Fageria et al., 2015; Rocha et al., 2011; Araújo et al., 2009). However, there are differences among the genotypes of common beans with regard to Mo responses, mainly due to seed size and Mo concentration (Vieira et al., 2014).

Considering that much more research is required to improve yield and $\mathrm{N}_{2}$ fixation in legumes, mainly in the common bean (Bambara \& Ndakidemi, 2010), the objective of this study was to evaluate the influence of Mo rates on the growth and amount of $\mathrm{N}$ fixed from the atmosphere in two Brazilian common bean cultivars, using the ${ }^{15} \mathrm{~N}$ isotope dilution technique.

\section{MAterial AND Methods}

The experiment was conducted in the year 2014, in a greenhouse at the Center of Nuclear Energy in Agriculture (CENA), in Piracicaba (Sao Paulo state, Brazil), using a completely randomized design in a factorial scheme $(5 \times 3)$ with three replications.

The treatments comprised four Mo doses (equivalent to $40,80,120$ and $240 \mathrm{~g} \mathrm{ha}^{-1}$ ), an untreated control (no Mo addition) and three cultivars of common bean: Aporé, which belongs to the carioca group; Ouro Negro, which belongs to the black group; and one non-nodulating common bean cultivar, NORH-54. This cultivar was used as non-fixing standard because it has the same root pattern, $\mathrm{N}$ absorption of sources available in the soil and similar maturity cycle.

The non-nodulating cultivar was used as a non-fixing reference plant to calculate the percentage of $\mathrm{N}$ derived from the atmosphere (\%Ndfa) in the nodulated cultivars. Both cultivars Aporé (carioca group) and Ouro Negro (black group) have an indeterminate growth habit, and the total crop cycle from sowing to maturity is 80 - 100 days.

The plants were grown in plastic pots of $3 \mathrm{dm}^{3}$ filled with one kilogram of air-dried soil collected from the top layer (0$0.20 \mathrm{~cm}$ ) of an Oxisol. The soil has the following characteristics according to the methodologies described in Camargo et al. (2009): $\mathrm{pH} \mathrm{CaCl}_{2}=4.0$; organic matter $=24 \mathrm{~g} \mathrm{dm}^{-3}$; phosphorus (P) extracted by resin $=4 \mathrm{mg} \mathrm{dm}^{-3}$; potassium $(\mathrm{K})=2.3 \mathrm{mmol}_{\mathrm{c}}$ $\mathrm{dm}^{-3}$; magnesium $(\mathrm{Mg})=2 \mathrm{mmol}_{\mathrm{c}} \mathrm{dm}^{-3} ; \operatorname{calcium}(\mathrm{Ca})=2$ mmol $\mathrm{dm}^{-3}$; aluminum $(\mathrm{Al})=0.9 \mathrm{mmol}_{\mathrm{c}} \mathrm{dm}^{-3}$; total acidity $(\mathrm{H}+\mathrm{Al})=47 \mathrm{mmol}_{\mathrm{c}} \mathrm{dm}^{-3} ; \operatorname{copper}(\mathrm{Cu})=0.8 \mathrm{mg} \mathrm{dm}^{-3} ; \operatorname{iron}(\mathrm{Fe})=$ $85 \mathrm{mg} \mathrm{dm}^{-3}$; manganese $(\mathrm{Mn})=1.9 \mathrm{mg} \mathrm{dm}^{-3}$; $\operatorname{zinc}(\mathrm{Zn})=0.9 \mathrm{mg}$ $\mathrm{dm}^{-3}$. The soil was mixed with washed sand (1:1 weight basis).

The lime was thoroughly mixed with the soil (calcium carbonate equivalent $=100 \%$ ) to raise the base saturation to $60 \%$, according to the official recommendation of São Paulo State (Raij et al., 1997). The soil was watered to $70 \%$ of the maximum water holding capacity with distilled water and incubated for 30 days.

Phosphorus and potassium fertilization was accomplished by applying $300 \mathrm{mg} \mathrm{kg}^{-1}$ of superphosphate triple and potassium chloride. Fertilization with micronutrients was performed by applying a water solution containing $0.5 \mathrm{mg} \mathrm{kg}^{-1}$ of boron (B) obtained from $\mathrm{Na}_{2} \mathrm{~B}_{4} \mathrm{O}_{7} .10 \mathrm{H}_{2} \mathrm{O}, 1.5 \mathrm{mg} \mathrm{kg}^{-1}$ of $\mathrm{Cu}$ from $\mathrm{CuSO}_{4} .5 \mathrm{H}_{2} \mathrm{O}$, and $3.0 \mathrm{mg} \mathrm{kg}^{-1}$ of $\mathrm{Zn}$ as $\mathrm{ZnSO}_{4} .7 \mathrm{H}_{2} \mathrm{O}$.

The seeds received a liquid inoculant containing the strain SEMIA 4080 of Rhizobium on the day of sowing. The seeds were not treated with insecticide or fungicide. Three seeds were sown in each pot and thinned to one plant five days after emergence. The ${ }^{15} \mathrm{~N}$ was applied as ammonium sulfate with $2.46 \mathrm{~atm} \%{ }^{15} \mathrm{~N}$ in excess to each pot, corresponding to $125 \mathrm{mg}$ of $\mathrm{N}$ per pot.

The dose of Mo used in the experiment was calculated according to the common bean plant density. For the cultivars Aporé and Ouro Negro, the recommendation is 240,000 plants per hectare. The rates evaluated were equivalent to $0,40,80,120$ and $240 \mathrm{~g}$ Mo for 240,000 plants per hectare, corresponding to the following rates: $0,0.17,0.33,0.67$ and $1.33 \mathrm{mg}$ of Mo per pot (one plant pot ${ }^{-1}$ ).

The Mo was applied 25 days after plant emergence, at the stage of the fourth fully developed trifoliate, in the form of sodium molybdate $\left(\mathrm{Na}_{2} \mathrm{MoO}_{4} \cdot 2 \mathrm{H}_{2} \mathrm{O}\right)$ at the soil surface. The irrigation was performed daily, manually, using distilled water, in the amount required to maintain substrate moisture near $70 \%$ of field capacity.

The plants were harvested at the stage of seed physiological maturity. The grains were separated from the shoot, and both parts were oven dried, weighed and finely ground using a roll-mill. The root systems were recovered by soil washing through a $2 \mathrm{~mm}$ aperture sieve, and the nodules were counted and weighted.

The ${ }^{15} \mathrm{~N}$ isotope composition was measured in the shoots and grains by coupling gas chromatography-mass spectrometry 
(GC-MS). The percentage of $\mathrm{N}$ derived from the atmosphere (\%Ndfa) was estimated by Eq. 1 :

$\% \mathrm{Ndfa}=\left(1-\frac{\text { atom } \%{ }^{15} \mathrm{~N} \text { excess (shoot or grain) of bean }}{\text { atom } \%{ }^{15} \mathrm{~N} \text { excess (shoot or grain) of non-fixing }}\right) \times 100$

Analysis of variance was performed. When the significance was verified by the F test, the Dunnet test $(\mathrm{p}<0.05)$ was used to compare the means of all doses of $\operatorname{Mo}(0,40,80,120,240 \mathrm{~g}$ $\mathrm{ha}^{-1}$ ) of inoculated cultivars with the non-nodulating cultivar. Linear and exponential regressions were used to evaluate the effect of the Mo doses. The values of $\mathrm{R}^{2}$ followed by the symbol $\left.{ }^{\star}\right)$ were significant at the 0.05 probability level.

\section{Results AND Discussion}

The Rhizobium inoculation had significant effects on the grain dry weight (GDW) and all the other measured parameters, which were significantly higher than in the nonnodulating cultivar, considering the means of all doses of Mo (Table 1).

The cultivars Aporé and Ouro Negro presented hundreds of nodules, while the non-nodulating cultivar formed an insignificant number (the number and size of nodules were very low, assumed to be zero) (Table 1), indicating that inoculation with the selected Rhizobium strain was effective for producing nodules in the common bean, contributing to $\mathrm{N}$ supply and helpful in improving grain production.

The common bean is considered a promiscuous host because there are many rhizobia species capable of producing nodules in the common bean, with a variety of bean-rhizobia interactions (Moreira \& Siqueira, 2006).

Nevertheless, some studies indicate that indigenous rhizobia strains are not efficient in common bean BNF, and these strains could hinder the introduction of more efficient strains (Vieira, 1998a), which is usually attributed to the lack of competitiveness against indigenous rhizobia, environmental conditions and plant genetic factors (Piha \& Munns, 1987; Hardarson et al., 1993).

Table 1. Nodule number ( $\mathrm{n}^{\circ}$ nod) and nodule weight (NW); shoot dry weight (SDW); total nitrogen in the shoot or grain ( $\mathrm{N}$ total); $\mathrm{N}$ derived from atmosphere $(\mathrm{Ndfa})$ and grain dry weight (GDW) measured in non-nodulating and nodulated cultivars of common beans, Aporé and Ouro Negro

\begin{tabular}{|c|c|c|c|c|c|}
\hline & Cultivar & & Non-nodulating ${ }^{\text {(a) }}$ & Aporé & $\begin{array}{c}\text { Ouro } \\
\text { Negro }\end{array}$ \\
\hline \multirow{2}{*}{ Nodules } & $\mathrm{n}^{\circ}$ nod & & 0 * & 166.15 & 325 \\
\hline & NW & $\left(\right.$ g plant $\left.^{-1}\right)$ & 0 * & 2.14 & 3.56 \\
\hline \multirow{4}{*}{ Shoot } & SDW & $\left(\right.$ g plant $\left.^{-1}\right)$ & 6.79 * & 8.71 & 9.97 \\
\hline & $\mathrm{N}$ total & $\left(\right.$ mg plant $\left.^{-1}\right)$ & 72.71 * & 95.21 & 120.59 \\
\hline & Ndfa & $\left(\right.$ mg plant $\left.^{-1}\right)$ & 0 * & 29.92 & 67.08 \\
\hline & Ndfa & (\%) & 1.23 * & 28.93 & 52.38 \\
\hline \multirow{4}{*}{ Grain } & GDW & $\left(\mathrm{g}\right.$ plant $\left.^{-1}\right)$ & 1.48 * & 10.57 & 10.16 \\
\hline & $\mathrm{N}$ total & $\left(\mathrm{mg} \mathrm{plant}^{-1}\right)$ & 48.40 * & 330.32 & 357.44 \\
\hline & Ndfa & $\left(\mathrm{mg} \mathrm{plant}^{-1}\right)$ & 0 * & 243.02 & 268 \\
\hline & Ndfa & $(\%)$ & 1.21 * & 63.99 & 72.23 \\
\hline \multirow{2}{*}{$\begin{array}{c}\text { Shoot + } \\
\text { grain }\end{array}$} & $\mathrm{N}$ total & $\left(\mathrm{mg} \mathrm{plant}^{-1}\right)$ & 121.11 * & 425.53 & 478.03 \\
\hline & $\mathrm{Ndfa}$ & (mg plant $\left.^{-1}\right)$ & 0 * & 272.94 & 335.08 \\
\hline
\end{tabular}

Means of all doses equivalent to $0,40,80,120,240 \mathrm{~g} \mathrm{ha}^{-1}$ of Mo. Means followed by * are significantly different by the Dunnet test $(p<0.05)$
These findings suggest that inoculation with the selected Rhizobium strain is an effective way to increase nodules on these cultivars of common bean and improve the $\mathrm{N}$ supply from biological fixation, which could be an alternative for smallholders farmers who cannot afford to purchase $\mathrm{N}$ fertilizers. However, it is important to emphasize that these results were obtained for only two Brazilian cultivars, Aporé and Ouro Negro, with all biotic and abiotic factors controlled. Therefore, it is necessary to validate these results with experiments in field conditions and in other cultivars.

These results corroborate with other reports. Pacheco et al. (2012) observed that seed inoculation with rhizobia markedly increased the nodulation in common beans. Hungria et al. (2003), in six field experiments performed in Oxisols in Southern Brazil, observed that a selection program of rhizobia strains was able to increase nodulation, BNF and the yield of common bean. Melo \& Zilli (2009) evaluated the BNF in five cowpea cultivars, observed increase in grain yield as a consequence of the inoculation.

Regarding Mo effects, the non-nodulating cultivar showed no response to the Mo supply for SDW, Total N, \% Ndfa in the shoot $\left(y=0.0002 x+1.216, R^{2}=0.101\right)$, GDW $(y=0.003 x+$ $\left.1.446, \mathrm{R}^{2}=0.005\right)$, Total $\mathrm{N}\left(\mathrm{y}=0.026 \mathrm{x}+43.89, \mathrm{R}^{2}=0.153\right)$ or $\% N d f a\left(y=-0.0003 x+1.245, R^{2}=0.082\right)$. For Aporé and Ouro Negro, the application of Mo showed no significant effect on SDW (Figure 1A) but did not influence GDW (Figure 2A) and enhanced $\mathrm{BNF}$ in the shoots and in the grain for both cultivars (Figure 1B, 1C, 1D and Figure 2B, 2C, 2D).

The Ndfa in the shoots increased progressively with the applied Mo doses (Figure 1C, 1D). The Ndfa in the Aporé shoots ranged from $4.04 \mathrm{mg} \mathrm{plant}^{-1}$ (control) to $58.34 \mathrm{mg}$ plant $^{-1}$ (240 $\mathrm{g} \mathrm{ha}^{-1}$ of Mo), corresponding to 5.6 and $52.83 \%$ of the total $\mathrm{N}$ content in the plant, respectively. For the cultivar Ouro Negro, the Ndfa ranged from 37.53 to $103.32 \mathrm{mg} \mathrm{plant}^{-1}$, corresponding to 35.34 and $66.2 \%$ of the total $\mathrm{N}$.

The Ndfa values were greater in the grains than in the shoots. For Aporé, the values of Ndfa in the grains ranged from $11.06 \mathrm{mg}$ plant $^{-1}$ (control) to $336.57 \mathrm{mg} \mathrm{plant}^{-1}\left(240 \mathrm{~g} \mathrm{ha}^{-1}\right.$ of Mo), corresponding to 13.48 and $78.27 \%$ of the total $\mathrm{N}$, while for Ouro Negro, the values ranged from 119.3 to $389.36 \mathrm{mg}$ plant $^{-1}$, corresponding to 62.16 to $83.15 \%$ of the total N (Figure $2 \mathrm{C}, 2 \mathrm{D})$. The non-nodulating cultivar NdfA values were 1.23 and $1.21 \%$ in the shoot and in the grain, respectively.

These BNF results for the shoots and grains of the inoculated cultivars demonstrated the importance of Mo application to increasing and maintaining nitrogenase and nitrate reductase activities throughout the plant growth cycle (Vieira, 1998b). Mo is a constituent of nitrogenase, a key enzyme in all $\mathrm{N}_{2}$ fixing microorganisms; consequently, nitrogen-fixing plants have a high Mo requirement, particularly in the root nodules (Hille, 1999; Marschner, 2012).

Araújo et al. (2009) observed an increase in grain yield with Mo supplementation up to a rate of $80 \mathrm{~g} \mathrm{ha}^{-1}$ of Mo. Fageria et al. (2015) also found that Mo application significantly increased the yield and yield components of common bean grown on a Brazilian Oxisol.

Rocha et al. (2011) observed that Mo fertilization increased the total $\mathrm{N}$ in the leaves and the grain yield for common beans cultivated under both conventional and no-tillage systems. 
A
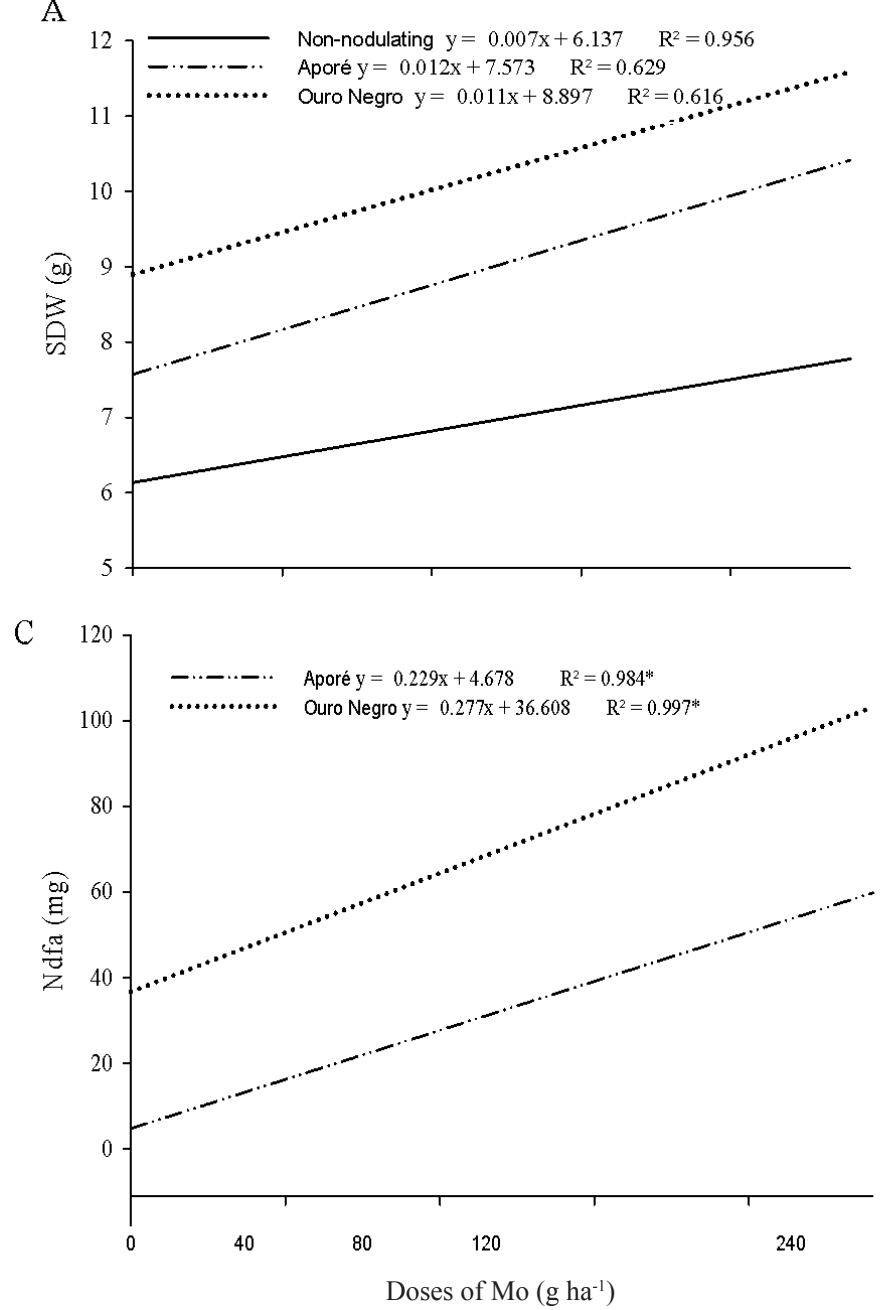
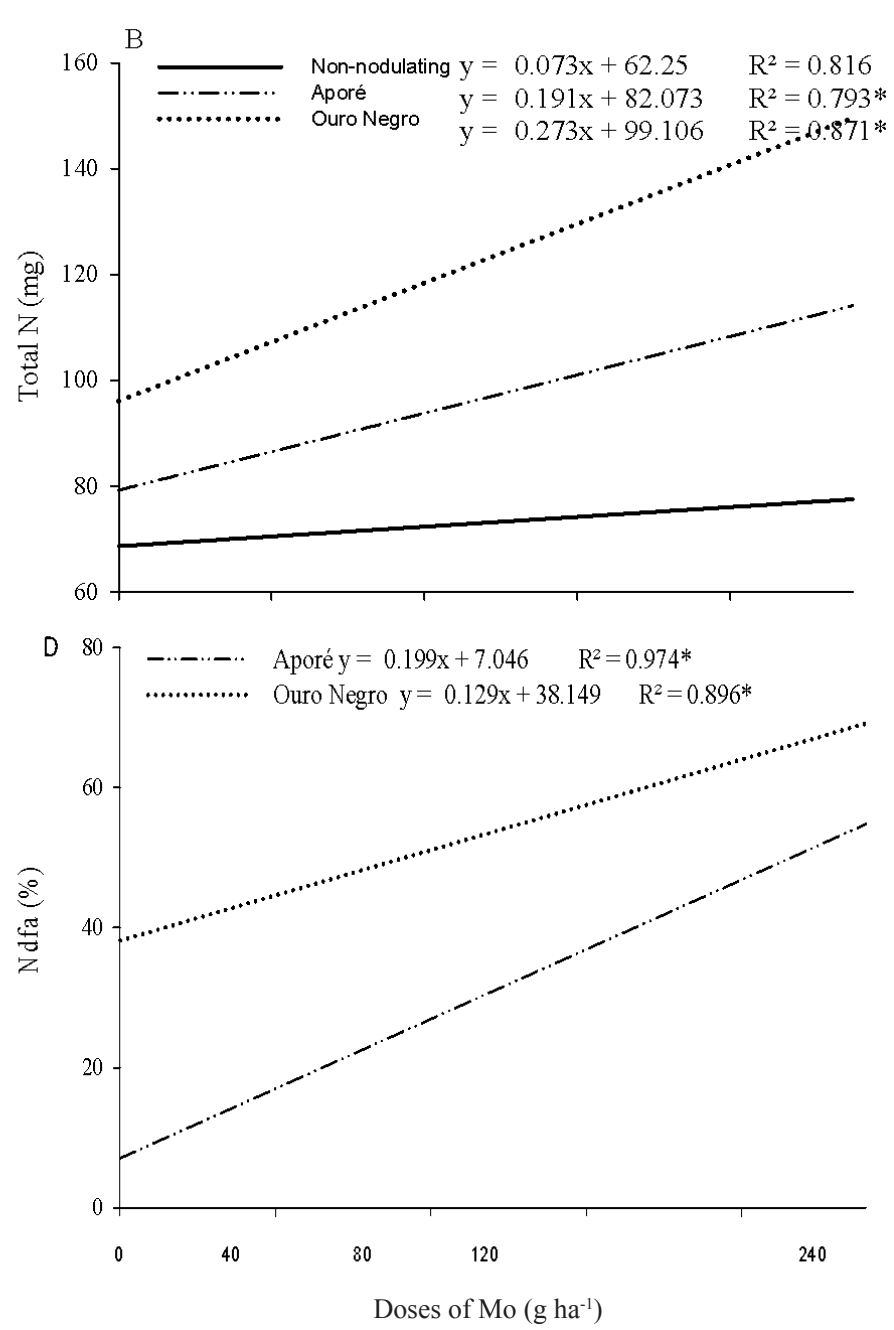

The $R^{2}$ values followed by * were significant at $p<0.05$

Figure 1. Effect of molybdenum (Mo) doses equivalent to $0,40,80,120,240 \mathrm{~g} \mathrm{ha}^{-1}$ of Mo on shoot dry weight (SDW) $(A)$, total nitrogen $(B)$ and $\mathrm{N}$ derived from atmosphere $(\mathrm{Ndfa})(\mathrm{C}, \mathrm{D})$ in common bean cultivars

Another study observed that the foliar application of $80 \mathrm{~g} \mathrm{ha}^{-1}$ Mo increased $\mathrm{N}$ fertilizer use efficiency by the common bean (Biscaro et al., 2011).

The Ouro Negro obtained higher amount of $\mathrm{N}$ derived from the atmosphere than Aporé. For Ouro Negro, the BNF contribution to the total $\mathrm{N}$ in the plant (sum of shoots and grains) was $335 \mathrm{mg}$ plant $^{-1}$, approximately $20 \%$ higher than for Aporé (272.94 mg), which might be due to the higher number and weight of nodules in the Ouro Negro (Table 1).

Even with no Mo supply, Ouro Negro presented higher Ndfa in the shoots and grains (Figure 1 and 2 C, D). In the treatment without Mo application, Ouro Negro had 37.53 $\mathrm{mg}$ in the shoots and $119.3 \mathrm{mg}$ in the grains, while Aporé presented 4.04 and $11.06 \mathrm{mg} \mathrm{plant}^{-1}$ in the shoots and the grains, respectively.

Although Aporé obtained a smaller amount of $\mathrm{N}$ derived from the atmosphere than Ouro Negro, the data showed that the BNF in Aporé was also responsive to the Mo application. The values of Ndfa in the shoots ( $\mathrm{mg}$ and \%) increased linearly with Mo supply (Figure 1C, D), whereas in the grains it was an exponentially adjusted curve (Figure 2C, D).

Both cultivars produced similar GDW values, as demonstrated by the mean values of the Mo doses (Table 1). In a previous study, Franzini et al. (2013) demonstrated that
Aporé and Ouro Negro yielded similar GDW values in an experiment with low $\left(2.2 \mathrm{mg} \mathrm{N} \mathrm{kg}^{-1}\right.$ soil) and high $\mathrm{N}$ content in the soil (200 $\mathrm{mg} \mathrm{N} \mathrm{kg}^{-1}$ soil).

The values of $\% \mathrm{Ndfa}$ found in this study were comparable to the values reported by Hardarson et al. (1993), who observed $70 \% \mathrm{Ndfa}$ in common beans grown in a field under favorable environmental conditions. Similarly, Rondon et al. (2007) showed values from 50 to $72 \%$.

Franzini et al. (2013), evaluating 25 bean genotypes, observed that BNF contributed, on average, $75 \%$ overall of the total $\mathrm{N}$ accumulated by the plants. The results from similar experiments utilizing the ${ }^{15} \mathrm{~N}$ natural abundance method showed values from 24 to $50 \%$ of $\% \mathrm{Ndfa}$ (Kimura et al., 2004) and from 49 to $61 \%$ (Viera et al., 1995).

There were no significant effects of Mo doses on the number and weight of nodules plant ${ }^{-1}$ in the inoculated plants. An absence of Mo effects was also observed in previous studies with Mo application (Vieira, 1998a). According to the author, Mo application decreased the plant nodule number but increased the nodule size, delaying senescence and maintained the effectiveness of the BNF for longer periods.

There was no negative effect of high doses of Mo in plants, possibly because legumes and no-legumes, which are dependent on BNF for their $\mathrm{N}$ supply, require more Mo to 
A

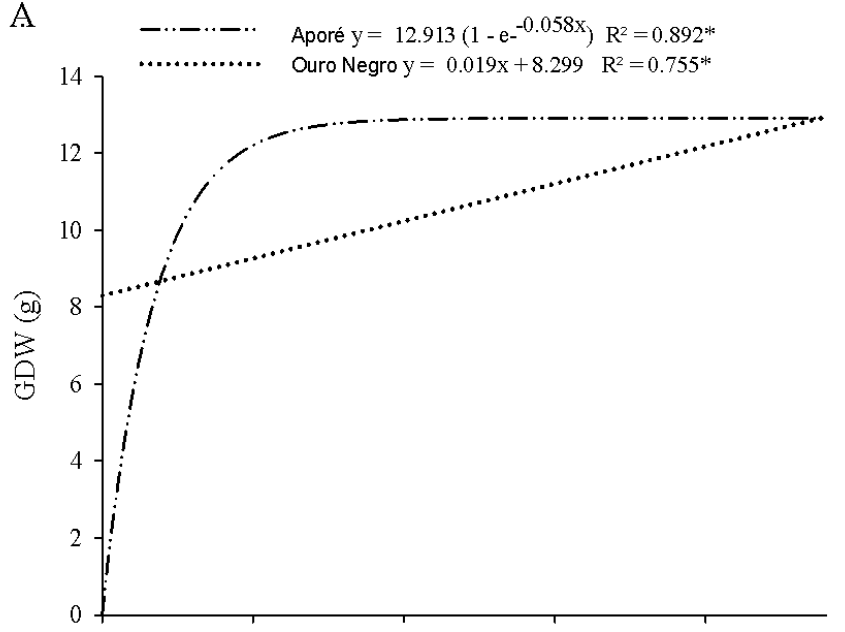

$\mathrm{C}$

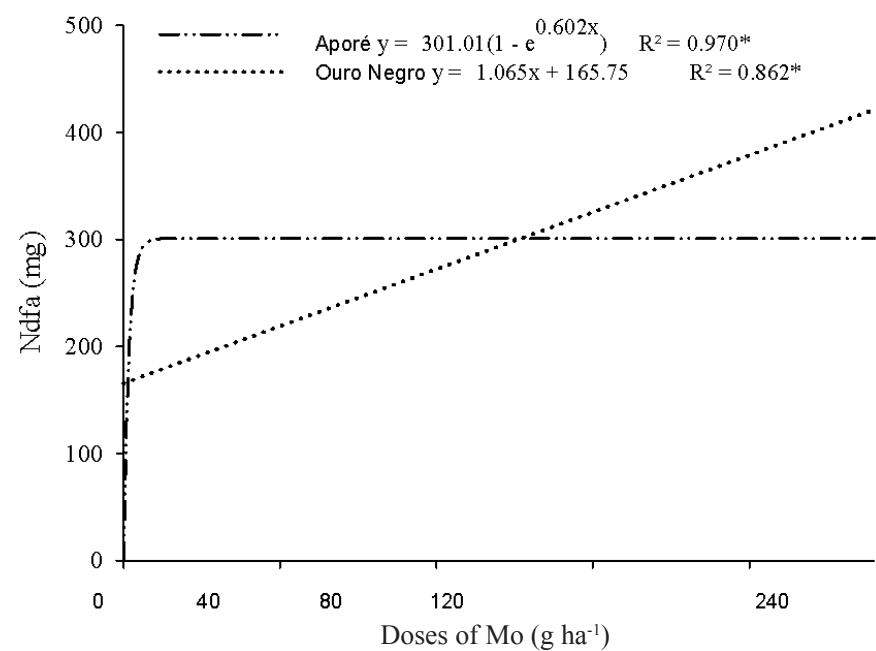

$\mathrm{B}$

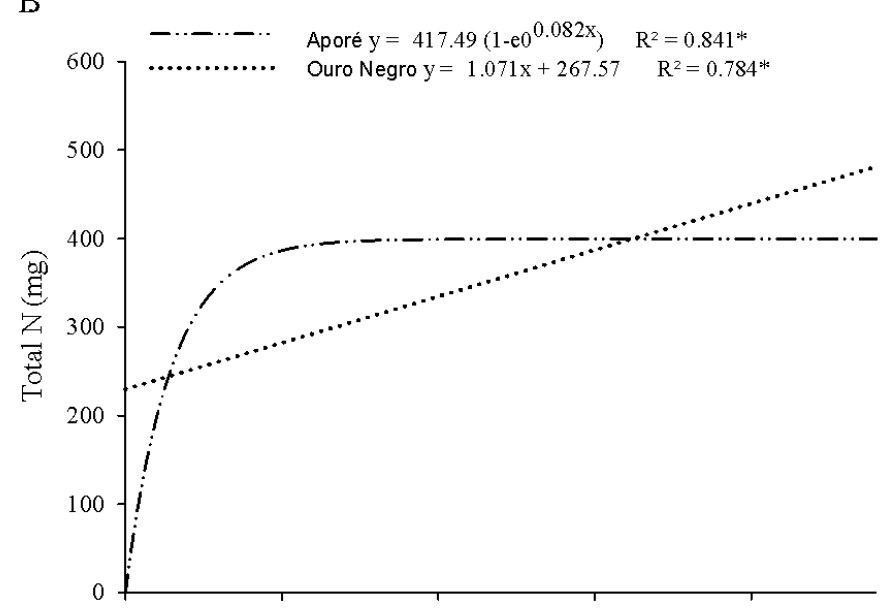

$\mathrm{D}$

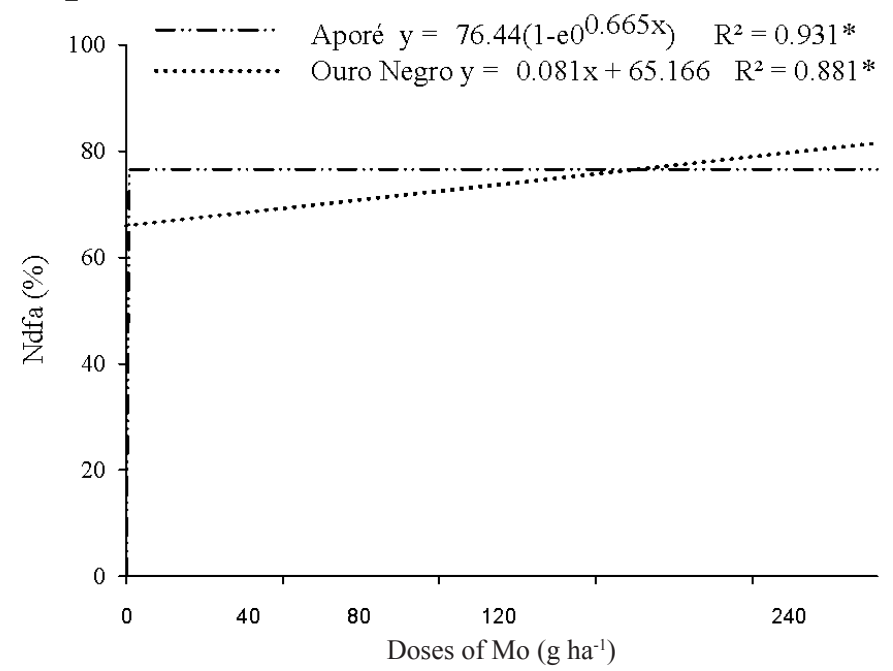

The $R^{2}$ values followed by * were significant at $p<0.05$

Figure 2. Effect of molybdenum (Mo) doses equivalent to $0,40,80,120,240 \mathrm{~g} \mathrm{ha}^{-1}$ of Mo on grain dry weight (GDW) (A), total nitrogen (B) and $\mathrm{N}$ derived from atmosphere (Ndfa) (C, D) in common bean cultivars

maintain the reduction of atmospheric $\mathrm{N}_{2}$ by the nitrogenase system (Hille, 1999; Marschner, 2012).

Vieira et al. (2010), studying the toxicity of high Mo rates sprayed on foliage, verified that doses as high as 4,000 $\mathrm{g} \mathrm{ha}^{-1}$ were not toxic to the common bean. Leite et al. (2007) evaluated foliar Mo application and verified that doses up to 2,560 $\mathrm{g} \mathrm{ha}^{-1}$ did not decrease the grain yield. Johansen et al. (2007) showed that $500 \mathrm{~g} \mathrm{ha}^{-1}$ Mo improved plant growth and resulted in chickpea seed yield responses ranging from 58 to $173 \%$.

\section{Conclusions}

1. The inoculation of the common bean with a recommended rhizobium strain in combination with the application of Mo contributed to improving biological nitrogen fixation and grain dry weight in two common bean cultivars.

2. The Ouro Negro cultivar obtained a higher amount of $\mathrm{N}$ derived from the atmosphere than Aporé, even with no Mo supply.

\section{ACKNOWLEDGEMENTS}

The 'Conselho Nacional de Desenvolvimento Científico e Tecnológico' (CNPq) and 'Fundação de Amparo à Pesquisa e Desenvolvimento Científico do Maranhão’ (FAPEMA).

\section{Literature Cited}

Araújo, P. R. A.; Araújo, G. A. A.; Rocha, P. R. R.; Carneiro, J. E. S. Combinações de doses de molibdênio e nitrogênio na adubação da cultura do feijoeiro comum. Acta Scientiarum Agronomy, v.31, p.227-234, 2009. https://doi.org/10.4025/actasciagron.v31i2.7033

Bambara, S.; Ndakidemi, P. A. The potential roles of lime and molybdenum on the growth, nitrogen fixation and assimilation of metabolites in nodulated legume: A special reference to Phaseolus vulgaris L. African Journal of Biotechnology, v.8, p.2482-2489, 2010.

Biscaro, G. A.; Freitas, J. S. R. P.; Kikuti, H.; Goulart, J. S. A. R.; Aguirre, W. M. Nitrogênio em cobertura e molibdênio via foliar no feijoeiro irrigado cultivado em solo de cerrado. Acta Scientiarum Agrononomy, v.33, p.665-670, 2011. https://doi.org/10.4025/ actasciagron.v33i4.6387

Boyd, E. S.; Peters, J. W. New insights into the evolutionary history of biological nitrogen fixation. Frontiers in Microbiology, v.4, p.201209, 2013. https://doi.org/10.3389/fmicb.2013.00201

Camargo, O. A.; Moniz, A. C.; Valadares, J. M. A. S. Métodos de análise química, mineralógica e física de solos do IAC. Campinas: IAC, 2009. 77p. Boletim Técnico, 106

Fageria, N. K.; Baligar, V. C.; Jones, C. A. Growth and mineral nutrition of field crops. 3.ed. Boca Raton: CRC Press, 2011. 560p. 
Fageria, N. K.; Stone, L. F.; Santos, A. B. Molybdenum requirements of dry bean with and without liming. Communications in Soil Science and Plant Analysis, v.46, p.965-978, 2015. https://doi.or g/10.1080/00103624.2015.1018523

Franzini, V. I.; Mendes, F. L.; Muraoka, T.; Trevisam, A. R.; AduGyamfi, J. J. Biological nitrogen fixation efficiency in Brazilian common bean genotypes as measured by ${ }^{15} \mathrm{~N}$ methodology. IAEA Tecdoc, p.299-309, 2013.

Hardarson, G.; Bliss, F. A.; Cigales-Rivero, M. R.; Henson, R. A.; Kipe-Nolt, J. A.; Longeri, L.; Manrique, A.; Peña-Cabriales, J. J.; Pereira, P. A. A.; Sanabria, C. A.; Tsai, S. M. Genotypic variation in biological nitrogen fixation by common bean. Plant and Soil, v.152, p.59-70, 1993. https://doi.org/10.1007/BF00016333

Hille, R. Molybdenum enzymes. Essays in Biochemistry, v.34, p.125137, 1999. https://doi.org/10.1042/bse0340125

Hungria, M.; Campo, R. J.; Mendes, I. C. Benefits of inoculation of the common bean (Phaseolus vulgaris) crop with efficient and competitive Rhizobium tropici strains. Biology and Fertility of Soils, v.39, p.88-93, 2003. https://doi.org/10.1007/s00374-0030682-6

Johansen, C.; Musa, A. M.; Kumar, R. A. O.; Harris, D.; Ali, M. Y.; Shahidullah, A. K. M.; Lauren, G. J. Correcting molybdenum deficiency of chickpea in the high barind tract. Journal of Plant Nutrition and Soil Science, v.170, p.752-761, 2007. https://doi. org/10.1002/jpln.200700249

Kimura, S. D.; Schmidtke, K.; Tajima, R.; Yoshida, K.; Nakashima, H.; Rauber, R. Seasonal $\mathrm{N}$ uptake and $\mathrm{N}_{2}$ fixation by common and adzuki bean at various spacings. Plant and Soil, v.258, p.91-101, 2004. https://doi.org/10.1023/B:PLSO.0000016539.73233.ec

Leite, U. T.; Araújo, G. A. A.; Miranda, G. V.; Vieira, R. F.; Carneiro, J. E. S.; Pires, A. A. Rendimento de grãos e componentes de rendimento do feijoeiro em função da aplicação foliar de doses crescentes de molibdênio. Acta Scientiarum Agrononomy, v.29, p.113-120, 2007.

Marschner, P. Mineral nutrition of higher plants. London: Academic Press, 2012. 889p.

Melo, S. R.; Zilli, J. E. Fixação biológica de nitrogênio em cultivares de feijão-caupi recomendadas para o Estado de Roraima. Pesquisa Agropecuária Brasileira, v.44, p.1177-1183, 2009. https://doi. org/10.1590/S0100-204X2009000900016

Moreira, F. M. S.; Siqueira, J. O. Microbiologia e bioquímica do solo. Lavras: UFLA, 2006. 729p.
Pacheco, R. S.; Brito, L. F.; Straliotto, R.; Peres, D. V.; Araujo, A. P. Seeds enriched with phosphorus and molybdenum as a strategy for improving grain yield of common bean crop. Field Crops Research, v.136, p.97-106, 2012. https://doi.org/10.1016/j.fcr.2012.07.017

Piha, M. I.; Munns, D. N. Nitrogen fixation potential of beans (Phaseolus vulgaris L.) compared with other grain legumes under controlled conditions. Plant and Soil, v.98, p.169-182, 1987. https://doi.org/10.1007/BF02374821

Raij, B. van; Cantarella, H.; Quaggio, J. A.; Furlani, A. M. C. Recomendação de adubação e calagem para o Estado de São Paulo. Campinas: IAC, 1997. 79p.

Rocha, P. R. R.; Araújo, G. A. A.; Carneiro, J. E. S.; Cecon, P. R.; Lima, T. C. Adubação molíbdica na cultura do feijão nos sistemas de plantio direto e convencional. Revista Caatinga, v.24, p.9-17, 2011.

Rondon, M. A.; Lehmann, J.; Ramiìrez, J.; Hurtado, M. Biological nitrogen fixation by common beans (Phaseolus vulgaris L.) increases with bio-char additions. Biology and Fertility of Soils, v.43, p.699-708, 2007. https://doi.org/10.1007/s00374-006-0152-z

Vieira, R. F. Foliar application of molybdenum in common bean. Effect on nodulation. Journal of Plant Nutrition, v.21, p.2153-2161, 1998a. https://doi.org/10.1080/01904169809365551

Vieira, R. F. Foliar application of molybdenum in common bean. Nitrogenase and nitrate reductase activities in a soil of low fertility. Journal of Plant Nutrition, v.21, p.2141-2151, 1998b. https:/doi. org/10.1080/01904169809365550

Vieira, R. F.; Paula Júnior, T. J.; Carneiro, J. E. S.; Queiroz, M. V. Genotypic variability in seed accumulation of foliar-applied molybdenum to common bean. Revista Brasileira de Ciências do Solo, v.38, p.205-213, 2014. https://doi.org/10.1590/S0100-06832014000100020

Vieira, R. F.; Salgado, L. T.; Pires, A. A.; Rocha, G. S. Conteúdo de molibdênio das sementes de feijoeiro em resposta a doses do micronutriente pulverizado sobre as plantas. Ciência Rural, v.40, p.666-669, 2010. https://doi.org/10.1590/S0103-84782010005000030

Viera, V. M. S.; Oliveira, O. C.; Souto, C. M.; Cadish, G.; Urquiaga, S.; Boddey, R. M. Use of different ${ }^{15} \mathrm{~N}$ labelling techniques to the contribution of biological $\mathrm{N}_{2}$ fixation to legumes. Soil Biology and Biochemistry Journal, v.27, p.1185-1192, 1995. https://doi. org/10.1016/0038-0717(95)00033-B

Vogt, G. A.; Balbinot, J.; Alvadi, A.; Michelangelo, M.; Backes, R. L.; Nicknich, W. Competitive ability of black common bean genotypes with weeds. Ciência e Agrotecnologia, v.37, p.397-403, 2013. https://doi.org/10.1590/S1413-70542013000500002 